\title{
US university told to reveal unfunded NIH application
}

A state court in Washington has ruled that the University of Washington in Seattle must allow an animal welfare group to see a proposal by one of its faculty for an experiment on rhesus monkeys even though the idea was not funded and the experiment has not been done. In a decision on 17 August, a King County superior court judge ordered psychologist Gene Sackett to release a copy of the proposal to the Progres sive Animal Welfare Society (PAWS), a local activist group. It is believed to be the first time a court in the United States has ordered the release of an unfunded grant application.

PAWS successfully argued that the Washington state public records laws permit the release of any grant proposal filed by a state-supported researcher regardless of the outcome. Had the proposal been funded by the National Institutes of Health (NIH), to which it had been sent, its contents could have been disclosed under the federal Freedom of Information Act, according to NIH officials.

Twenty-nine other organizations, including NIH and several other US universities, filed declarations on behalf of the University of Washington. They argued that release of the information violates an investigator's right to privacy and could reveal secret research formulas, designs or data, as well as setting a precedent for other state courts. The decision - if it stands - might also allow scientists to take ideas from a colleague's application, refine them and then submit them for funding in competition with the original proposal, says Joanne Belk, NIH's acting freedom of information officer.

But the judge ruled that neither state law nor the First Amendment of the US constitution that protects freedom of speech prohibit the release of such unfunded applications. He did, however, allow the university to withhold budget figures, personal information about the investigator and some financial calculations. Although the state has unusually liberal disclosure laws, according to Laurel Wilkening, provost of the University of Washington, "these things tend to cascade" and could prompt similar orders to release research documents in other states.

The experiment, called "Effects of socialization on forebrain development", would have used 21 infant rhesus monkeys, 13 of which would have been deprived of contact with other monkeys shortly after birth. Sackett speculates that the isolation may cause self-destructive tendencies in the monkeys that would produce changes in their brains; such a finding might someday lead to treatments of children who exhibit similar behaviour. NIH declined to fund the proposal in June 1991 after widespread community and campus protest. University officials have not yet decided whether to appeal.

Christopher Anderson

\section{Genetics-and-crime conference cancelled in clash with NIH}

Washington. Organizers last week cancelled a controversial conference on genetics and crime after the US National Institutes of Health (NIH) refused to release money it had previously awarded for the meeting.

Attacked as racist by African-American groups, the conference was scheduled to bring together geneticists, ethicists and criminologists on 9-11 October to discuss whether there were genetic links to criminal behaviour. But critics complained that the promotional material seemed to assume such a controversial link and the NIH froze its $\$ 78,000$ grant (see Nature 358, 357; 1992) from the ethics, legal and social implications programme of the National Center for Human Genome Research. Although the conference's organizer, David Wasserman of the University of Maryland, convened a panel last month to address objections and submit an alternative list of speakers and topics, the debate only became more acrimonious.

Last week, NIH wrote a three-page letter to Wasserman accusing him of "irresponsible" behaviour. It called the conference "fatally flawed" and rejected the alternative agenda that Wasserman had proposed. Although the conference, sponsored by the university's Institute for Philosophy and Public Policy, can no longer be held on schedule, Wasserman still wants NIH to "recognize its obligation to release the money". Christopher Anderson

\section{NEWS IN BRIEF}

Washington. US biotechnology companies are concerned that the US government is about to lump them in a class with Wall Street investment firms, forcing them to disclose internal details of their research programmes.

The Securities and Exchange Commission (SEC) has warned several cash-rich biotechnology companies without products on the market that it may label them as 'investment companies' because the . companies have large cash reserves often more than $\$ 100$ million - and tend to buy large amounts of high-yielding securities until the money is needed to meet research costs. Start-up companies may take years to exhaust such reserves.

This practice has apparently caught the notice of the SEC, which regards such investments as one sign that a company should be monitored more closely. Should the SEC follow its proposed redesignation, affectecl biotechnology companies would have to comply with yet another layer of regulation, possibly including higher taxes, disclosure requirements and financial restrictions. The Industrial Biotechnology Association has met SEC officials on the issue and will discuss a response at a meeting of its board of directors on 23 September.

C.A.

Munich. The Collége de France, the elite Paris university whose select band of professors enjoy great prestige in France, is opening its doors to the world. Once the bastion of nationalist culture, the Collége is for the first time allowing foreigners to be considered for its 52 permanent chairs, 22 of which are occupied by scientists. This decision follows the success of a single chair, established in 1989, that offers a yearly contract to someone from another country in the European Communities. Professors are not required to have any specific qualifications, nor are they required to follow any particular curriculum. Their lectures, which must be changed every year, are open to the public.
A.A.

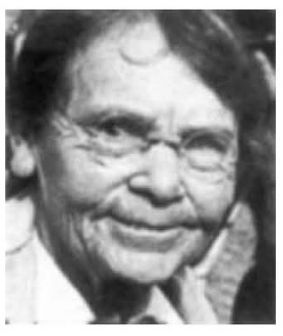

Barbara Mcclintock
Washington.

Barbara

McClintock, whose discovery of transposable genetic elements won her a Nobel Prize in 1983 and a crowning place in scientific history, died last week after a short illness. Her

pioneering work on 'jumping genes' in maize in the 1940 s and 1950 s predated all but the vaguest descriptions

of genes themselves. Associated with the Cold Spring Harbor (NY) Laboratory for more than 50 years, she continued to work in genetics, inspiring generations of scientists. A collection of essays by leading geneticists on McClintock's scientific and personal influence was published earlier this year to mark her ninetieth birthday (see Nature 358, 631; 1992). 